Review

\title{
A Critical Review of Recent Literature on Populism
}

\author{
John Abromeit \\ Department of History, State University of New York, Buffalo State, Buffalo, NY 14216, USA; \\ E-Mail: abromejd@buffalostate.edu
}

Submitted: 19 August 2017 | Accepted: 18 September 2017 | Published: 29 December 2017

\begin{abstract}
This is a review article of the following five recent studies on populism: 1) Ruth Wodak's The Politics of Fear: What RightWing Populist Discourses Mean (Sage, 2015); 2) Benjamin Moffitt's The Global Rise of Populism: Performance, Political Style and Representation (Stanford University Press, 2016); 3) Cas Mudde and Cristóbal Rovira Kaltwasser's Populism: A Very Short Introduction (Oxford University Press, 2017); 4) Jan-Werner Müller's What is Populism? (University of Pennsylvania Press, 2016); and 5) John B. Judis' The Populist Explosion: How the Great Recession Transformed American and European Politics (Columbia Global Reports, 2016). The review argues for a return to early Frankfurt School Critical Theory to address some of the shortcomings of these studies.
\end{abstract}

\section{Keywords}

authoritarianism; Frankfurt School; left-wing populism; populism; right-wing populism

\section{Issue}

This review is part of the issue "Populism and the Remaking of (II)Liberal Democracy in Europe", edited by Lars Rensmann (University of Groningen, The Netherlands), Sarah de Lange (University of Amsterdam, The Netherlands) and Stefan Couperus (University of Groningen, The Netherlands).

(C) 2017 by the author; licensee Cogitatio (Lisbon, Portugal). This article is licensed under a Creative Commons Attribution 4.0 International License (CC BY).

After a period of quiescence in the postwar decades, the appeal of right-wing populist movements and parties has increased steadily in Europe and the U.S. since the 1980s. Although this appeal has ebbed and flowed, the Great Recession of 2008 reinforced these tendencies, as demonstrated subsequently by the rise of Tea Party and Donald Trump's shocking victory in the 2016 presidential election in the U.S.; the successful British referendum to leave the EU; the continued growth and stunning electoral performances of established right-wing populist parties in Western Europe, such as the French National Front and the Austrian Freedom Party; and, in Eastern Europe, the rise to power of right-wing populist parties in Poland and Hungary. These dramatic events have inspired a plethora of new scholarship on populism, which has moved beyond older debates about the agrarian vs. urban roots of populism, or whether or not populism is even a useful term for social scientists (e.g. Gellner \& lonescu, 1969). More recent scholarly debates have focused on how to define populism; whether it expands democracy or represents a threat to it; how new forms of media abet or inhibit populist movements; whether or not a charismatic leader is a necessary for a successful populist movement; and whether or not populists are capable of maintaining power once elected. Not surprisingly, this new literature on populism has been dominated by political scientists, with less frequent contributions from sociologists and media scholars. In contrast to the older debates about populism, historians have been-with some exceptions (e.g. Abromeit, Chesterton, Marotta, \& Norman, 2016; Finchelstein, 2017)-notably absent. Although scholars who study populism in different regions have produced solid comparative studies (e.g. Mudde \& Kaltwasser, 2012), truly interdisciplinary approaches to populism have also been lacking. In what follows, I will survey a few of the most significant recent works on populism, with a view to some of the blind spots produced by the aforementioned peculiarities of this new wave of scholarship. I will also refer throughout to the studies of fascism and right-wing populism produced in the middle decades of the twentieth century by the Frankfurt School critical theorists. Their truly inter- 
disciplinary approach still offers many valid insights into the socio-economic roots and social-psychological mechanisms that underlie populist movements. Largely forgotten or caricatured today, their studies of populist and authoritarian movements could still provide an excellent point of departure for new, interdisciplinary approaches to populism.

In her study, The Politics of Fear: What Right-Wing Populist Discourses Mean, Ruth Wodak draws upon the "discourse-historical approach" (DHA) to analyze the main rhetorical strategies used by right-wing populist parties and politicians. She focuses primarily on Europe, but also casts an occasional glance at the U.S. and the Tea Party. Her book was published in 2015, before Donald Trump's rise to political power. She spells out briefly the methodological and theoretical assumptions of the DHA in the third chapter, thereby justifying her focus throughout on texts (written, spoken or visual) and the meanings they attain only within specific contexts. She argues repeatedly that there can be no one single overarching explanation of the resurgence of right-wing populism in Europe and the U.S. in the past two decades, and that right-wing populist discourses have completely different meanings in different local contexts. At the same time, however, she does identify certain tendencies that transcend what she calls the "micro-politics" of right-wing populism. For example, among the books under consideration here, she provides the richest analysis of the "re-nationalization" of politics in Europe that right-wing populist parties have both spearheaded and benefited from. After providing her reader with some basic background information about right-wing populism and scholarly discussions of it in the first two chapters, and her own theoretical assumptions in chapter three, Wodak focuses in the next four chapters on four of the most important content areas of right-wing populist rhetorical "topoi", namely, nationalism, anti-Semitism, performance and the media, and gender. In the concluding chapter, she ties the various strains of her arguments together, but also presents an original and provocative argument about the "Haiderization" of European politics, to which I will return below. Interspersed unevenly throughout these eight chapters are a series of 15 "vignettes", in which Wodak provides more detailed analysis of right-wing populist texts from specific instances or debates, such as an interview with British National Party politician Nick Griffin, in which he discusses accusations of Holocaust denial, or a series of racist and xenophobic posters supporting the Swiss People's Party. These vignettes are undoubtedly one of the main strengths of Wodak's study, not only because they give her a chance to provide the close textual analysis favored by DHA, but also as a source of empirical case studies, which shed much light on the differences and similarities between various right-wing populist parties in Europe.

It is perhaps not a coincidence that Wodak's discussion of the main content areas of right-wing populism begins with nationalism. Following Theodor Adorno, whose statement, "identity is the prototype of ideology", she cites, Wodak illustrates the creeping "re-nationalization" of European politics in the past two decades with a discussion of language, immigration and naturalization policies. She notes, for example, that in 1998 only six European states had language and/or citizenship exams, whereas by 2010 that number had increased to 18 , and by 2013 to 23 (Wodak, 2016, p. 88). She argues that such tests are repressive insofar as they deny the "obvious fact" that "Europe and the EU have become countries of immigration, diverse, multilingual and multicultural" (Wodak, 2016, p. 186). Even when right-wing populist parties' success at the ballot box has been limited, they have had an outsized influence in the resurgence of nationalism, insofar as mainstream parties have often taken over their language and even policy proposals in order to outflank them politically. This is one aspect of what she describes as a "normalization of rightwing populist policies", which has had as a consequence "that almost the entire political spectrum moves to the right" (Wodak, 2016, p. 184). In the final chapter of her book she illustrates this process in more detail with an illuminating discussion of the electoral breakthrough of the Austrian Freedom Party, which received $27.2 \%$ of the vote in national elections in October 1999-enough to form a governing coalition the following February with the Christian-Democratic Austrian People's Party. In response, $14 \mathrm{EU}$ member states imposed sanctions on Austria, but these sanctions were soon lifted and an EU panel concluded that the new governing coalition did not violate EU law. Wodak argues that these events were a decisive turning point: "his [Haider's] ascension marks the threshold when right-wing populist parties started to become acceptable for being integrated into a national government in an EU member state" (Wodak, 2016, p. 178). Although Wodak makes a strong case for the "Haiderization of Europe", her almost complete neglect of right-wing populism in France and Italy, begs the question of how Jean-Marie Le Pen's National Front and Silvio Berlusconi's Forward Italy parties, which were both influential-albeit in different waysbefore Haider's electoral breakthrough, also anticipated and normalized right-wing populist politics in Europe.

In the fifth chapter Wodak makes an intervention in the ongoing debate about the role of anti-Semitism in right-wing populist parties and whether or not it hasas some commentators have recently claimed-been displaced by Islamophobia among "second-generation" leaders, such as Marine Le Pen or Heinz Christian Strache, who have arguably distanced their respective parties from the open anti-Semitism of their successors and have instead moved toward a chauvinistic concept of "Western Civilization" allegedly under attack by Islam. Wodak convincingly criticizes this thesis and argues that anti-Semitism is just as important as ever for right-wing populist parties in Europe, even if it must now be expressed in coded forms. She makes clear that Islamophobia and anti-Semitism can and do continue to exist 
side by side. In chapter six Wodak examines the rightwing populist politics of charisma and their use of traditional and newer social media. Although she criticizes a purely psychological concept of charisma, which locates its source in the exceptional "gifts" of the populist leader, her own definition of term as mastering specific performances in specific contexts remains rather formalistic and points to the limits of her predominantly linguistic and text-based approach. In this same chapter she nods approvingly to the analysis of the "Führer personality" by Leo Lowenthal-Theodor Adorno's erstwhile colleague at the Institute for Social Research. What sets Lowenthal and Adorno's analyses of charisma and authoritarianism apart from her own, however, was their much more fully developed social-psychological conceptual apparatus. Their combination of the psychoanalytic concept of "identification" with an analysis of the historically shaped character structures that exist in any given society, made it possible for them to grasp the actual emotional mechanisms at work in charisma in a way that linguistic and textual analysis alone cannot. That said, Wodak's careful analysis here of the mendacious rhetorical techniques used by right-wing populist leaders sheds much light on the subject-and continues felicitously the tradition of earlier studies along the same lines, such as Lowenthal and Norbert Guterman's Prophets of Deceit: A Study of the Techniques of the American Agitator. In chapter seven Wodak turns her attention to an aspect of right-wing populist rhetoric that has often been neglected by other commentators: gender. She notes that more men-and more working-class men, in particularvote for right-wing populist parties than do women, especially in Western Europe. At the same time, she offers a nuanced and compelling explanation of why women occupy important leadership roles in many of the parties in both Europe and the U.S. In more secular Western Europe, Marine Le Pen and Pia Kjaersgaard focus on the hijab or burqa wearing Muslim as the primary symbol of the threat Islam poses to "Western" ideals of gender equality, whereas in the more Christian U.S. populist politicians like Sarah Palin and Michelle Bachman view abortion and even contraception as threats to the traditional, white patriarchal family. Drawing once again on Adorno, Wodak argues that the reactionary attitudes towards gender characteristic of many right-wing populist male voters are linked-in both Europe and the U.S. - to the real and perceived loss of status of white working-class men since the 1970s and that these attitudes co-exist and reinforce other aspects of the "syndrome" of the authoritarian personality, such as ethnocentrism, anti-Semitism and xenophobia.

In The Global Rise of Populism: Performance, Political Style, and Representation, Benjamin Moffitt (2016) attempts to stake out an innovative interpretation of populism as a political style, whose essence lies primarily in mediated performances by leaders and not in specific content or ideology. Moffitt also attempts to move beyond the limits of most recent commentary on populism by addressing it as a truly global phenomenon, with common characteristics everywhere. To make good on his claim for global coverage, he uses as case studies 28 populist leaders from around the world. The other main way in which Moffitt tries to set his study apart from the voluminous older and newer literature on populism lies in his focus on the dramatic transformation of the media in the past two decades and its effects upon politics. Moffitt argues that populism is qualitatively different today because of the new media, and that the new media has benefited and advanced populism more than any other form of politics.

Moffitt begins with an overview of the literature on populism, in which he discerns four distinct approaches: populism as an ideology, a political strategy, a discourse or rhetoric, or a political logic. He proceeds to explain how his own interpretation of populism as a political style differs from these approaches. According to him, all forms of populism appeal to "the people" against "the elite"; they flaunt bad manners and flout politically correct forms of behavior; and they seek to mobilize supporters with hyperbolic warnings about existing or imminent crises and threats. Furthermore, populism differs from genuine political ideologies, such as liberalism or socialism, in that it relies much less on stable principles than on specific ways of performing politics. He argues that, for populists, politics is more about how the message is delivered than the actual message itself. Moffitt cites approvingly the "constructivist" and "performativist" turns in the social sciences as informing his position. He notes as an advantage of his approach the ability to recognize "the populist style in politics" in many different contexts, and across the traditional divisions between the left and the right. Consequently, Moffitt makes no effort to distinguish left- and right-wing forms of populism. Instead, he contrasts populism as a whole to non-populist forms of politics, such pluralism and especially technocracy, whose appeal to expertise, good manners and stability he views as the diametric opposite of populism.

In chapter four of his study, Moffitt turns his attention to the much-debated role of the leader in populism. He argues-against Cas Mudde and others-that downplaying the role of the leader betrays a Eurocentric approach to populism; the centrality of the leader to populist movements and parties is the rule, rather than the exception, when one views populism as a global phenomenon. For Moffitt, "it is the leader that should be our main focus when studying the phenomenon, given that they are the figures that ultimately 'do' populism" (Moffitt, 2016, pp. 51-52). Populism differs from traditional political ideologies also in that the leader does not represent but actually embodies "the people". But, as Moffitt points out insightfully, charisma is not necessary to become a living symbol of the "general will"; more important are convincing "performances of ordinariness and outsiderness", which make it possible for people to identify with the leader. Moffitt states that 
he agrees with Freud's theory of group psychology, according to which such "symbolic unification of the group" functions as a process of identification, although he does not discuss the process of introjection, which leads to the formation of libidinal bonds between the leader and his/her followers. ${ }^{1}$ Moffitt's reference to Freud here is isolated and social-psychological categories of any kind are absent in the remainder of his book. As with Wodak's discourse-analytical approach, Moffitt's emphasis on the media and performance provides few conceptual tools that could explain why certain political techniques are successful, while others fail. To his credit, Moffitt attempts to address this problem in chapter six, which focuses on the audience for populism. Qualifying his claim in chapter four somewhat about the primacy of the leader, Moffitt admits here that not all attempts to perform populism are successful and the populist subject is not simply "interpellated" in a passive way, but has an active role in choosing which performances it accepts, through individuals' decision to listen or not, or to join or vote for specific parties. Although Moffitt is certainly correct to emphasize that the relationship between the populist leader and his or her supporters is thoroughly mediated-not direct-his own concept of mediation remains unmediated insofar as it focuses solely on media performances and not the larger social and historical context in which those performances occur. His invocation of Guy Debord's Society of the Spectacle here to support his claims demonstrates clearly Moffitt's inadequate mediation of media appearance with social reality. For Debord-thoroughly schooled in Hegel, Marx and Lukács-the "spectacle" was precisely not just the media, but rather the most advanced form of a capitalist society, in which even images have been seized by the commodity form. Moffitt has good insights into the key role that carefully constructed, mythical images of "the people" play in the populist ideological repertoire, but he lacks the conceptual tools to decipher such social heiroglyphics.

In chapter seven, Moffitt shifts back to a more constructivist argument, with a critique of commentators who posit a strong, or even weak causal link between crises and populism. Against them, Moffitt views "crisis as a phenomenon that can be experienced only through mediated performance" (Moffitt, 2016, p. 118) and he avers that "a crisis only becomes a crisis when it is perceived as a crisis" (Moffit, 2016, p. 120, emphasis his own). One wonders if the legions of persons who lost their jobs and homes after the Great Crash in 1929 or the Great Recession in 2008-which led directly to an upsurge of left- and right-wing populist movements in Europe and the U.S. - just needed to adjust their perceptions. Moffitt does have a worthwhile point to make here, namely, that the performance of crisis is essential to the populist's cultivation and manipulation of fear among its audience, but severing the link completely from real social crises and populism goes too far. In the penultimate chapter Moffitt turns his attention to debates about whether populism is good or bad for democracy. After a brief, but lucid outline and analysis of the main positions of the three main camps-those who view populism as a threat to democracy, those who view it as a deepening of democracy, and those who take an equivocal approach-Moffitt sides with those who remain agnostic and insists that populism will have different consequences in different contexts. Incongruously, he criticizes Cas Mudde-whom he correctly places in the third camp-for not making his normative commitment to liberal democracy and pluralism clear enough, while at the same time arguing that populism often serves as a corrective to overly liberal conceptions of democracy. Moffitt's elaboration of the positive and negative effects populism can have in different contexts is illuminating, but it would seem that his own normative commitments are weaker than Mudde's. Moffit concludes with the undeniable observation that populism has experienced a revival on a global scale in the past few decades and that it is here to stay. His other parting claim, that analyses of populism must keep pace with times, is well taken, although his own passing and underdeveloped reference to Freud can also serve as a reminder that "older" conceptual approaches to populism and group psychology should not be consigned to the proverbial dustbin of history. As anyone who has suffered through The Triumph of the Will knows, right-wing populists' discovery of "new media" long predates the twenty-first century.

In Populism: A Very Short Introduction, one can find a useful distillation of the reflections of two veteran scholars of populism, Cas Mudde and Cristobál Rovira Kaltwasser (2017). The former is a leading authority on rightwing populist parties in Europe and the latter an expert on populism in Latin America, although both have also published comparative studies of populism in different regions. Parting ways immediately with those who reject populism as a merely polemical term, or one too vague to be helpful for scholarly analysis, the authors argue that it is possible to provide a minimal definition of populism which grasps its common features across space and time, and distinguishes it from other political movements, parties and/or ideologies. Accordingly, they define populism as a "thin-centered ideology" which necessarily includes three core concepts. They use "ideology" as a neutral, not an inherently pejorative term, more akin to a "worldview" than "false consciousness". By "thincentered" they refer to the fact that populism is less comprehensive than other political "ideologies", such as liberalism or socialism, which makes it possible, indeed necessary, for populism to be combined with other ideologies in order to become an effective political force. The three core concepts that define populism, according to them, are "the people", "the elite", and "the general will". Following or alluding to Ernesto Laclau, they refer to the first

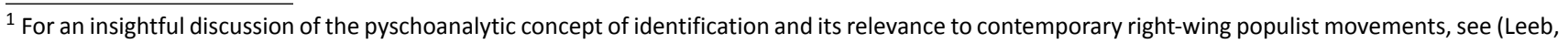
in press).
} 
two concepts as "empty signifiers", which means that one must examine the particular incarnation of populism in a local context to determine how the opposition between "the people" and "the elite" is constructed. With the concept of "the general will", they allude, of course, to Rousseau and his critique of representative government, but also to what they refer to as the "monist core of populism" (p. 18), which brings populism into close proximity with the later, right-wing and (proto-)fascist political theory of Carl Schmitt. Mudde and Kaltwasser's choice of Rousseau and Schmitt to illustrate the theoretical underpinnings of populism raises the question of the relationship of populism to classical republicanism, but also the question of the historical transformation of populism from a left- to a right-wing ideology between the French Revolution and the emergence of fascism and other new, radical right-wing movements in the late nineteenth and early twentieth century; but they don't pursue these important questions here. ${ }^{2}$ In any case, the "monist" character of populism highlights its inherent preference for a purported "general will" over any individual or minority rights. Later in the book, they also define populism as compatible with democracy, but a potential threat to liberal democracy. Finally, they also define their approach to populism as "ideational"; for them, in other words, "populism is first and foremost a set of ideas" (Mudde \& Kaltwasser, 2017, p. 62), which can be used in different ways by different actors. This approach has the advantage of permitting them to move beyond sterile debates about whether populism is primarily a movement or a party, or whether populism is tied to a specific type of leader, or to a leader at all.

In the second chapter the authors examine briefly the changing forms of populism that have existed in different regions of the globe in the twentieth and twentyfirst centuries. They provide a good overview of the transformation of populism in the U.S. over the course of the twentieth century from a predominatly progressive, to a predominantly reactionary movement-here again, however, without any attempt to explain why this shift occurred. They also helpfully point to the centrality of producerism, which defines "the people" as virtuous producers and "the elite" as immoral parasites, to both progressive and reactionary forms of populism in the U.S. They approach Latin American populism by way of a historical periodization that distinguishes three main waves: classical populism (1929-1969), represented paradigmatically by Juan Peron; neo-liberal populism (the 1990s), represented by Alberto Fujimoro and Carlos Menem; and left-wing populism (1998 to the present), represented by Hugo Chavez and Evo Morales. Their historical narrative of European populism begins with the Russian narodniki movement, which was itself unsuccessful, but which inspired several successful agrarian populist movements in Eastern Europe. Problematically, they erect a firewall between fascism and populism by claiming rather simplistically that fascism was an eli- tist movement. Here they overlook the crucial anti-elitist elements of fascist ideology, which set it apart from traditional European conservatism and made it so appealing the new radical nationalist movements that had begun to emerge in France, Germany and other European countries at the end of the nineteenth century. These movements should be seen as key sources of twentiethcentury European populism-and not just the Russian narodniki. They point out correctly that populism disappeared almost entirely in Europe in the prosperous postWorld War II decades, and did not reemerge as a force to be reckoned with until the end of the 1990s. Striking from our perspective today in relationship to both Europe and the U.S., where populism also languished in relative obscurity in the post-war period, is the correlation between the Keynesian economic policies and stronger welfare state, on the one hand, and the notable absence of populism, on the other. The correlation between the resurgence of populism in the 1990s and the spread of neo-liberal ideas that preceded and accompanied it, is equally striking. It is even more striking if one views the conservative shift in Western European politics in the late 1970s and early 1980s-represented by Thatcher in Britain or Kohl and the Tendenzwende in West Germany-as the watershed moment in the recrudescence of populism, rather than the late 1990s, as do the authors. Who would deny that the former shift was also characterized by a powerful resurgence of the xenophobia that would figure so prominently in later European populist movements? Mudde and Kaltwasser are open to arguments that posit not merely correlation, but causal links between the rise of neo-liberalism and rightwing populism in Europe and the U.S., but it is-as we shall see-John Judis who explores these links most compellingly. Mudde and Kaltwasser also mention in passing populist movements in other parts of the globethereby agreeing with Moffitt that populism is truly a global phenomenon-but with the limited amount of space allotted to them in a "very short introduction", their discussion remains necessarily superficial.

Chapter three provides an analytically sharp and useful discussion of the three main types of populist mobilization: top-down personalist leadership, bottom-up social movements and the mixed form of the political party. Mudde brings his formidable knowledge of European right-wing populist parties to bear here, to demonstrate-pace Moffitt-that populist parties can not only thrive without charismatic leaders, but that such charisma is often a function of the much more durable party form. In chapter four Kaltwasser offers a plausible explanation of how and why the charismatic strongman has been so successful in the Latin American context, but he and Mudde also explain that such a leader is one of several types that have proven successful in populist parties and movements. Other types include women, entrepreneurs, ethnic leaders or "insider-outsiders" who can succeed in gaining acceptance as the "vox populi".

\footnotetext{
${ }^{2}$ For an examination of this problem, see (Abromeit, 2016).
} 
Although they distinguish helpfully between different types of leaders, they seem to agree with Wodak and Moffitt that all forms of populist leadership involve a process of identification between the supporters and the leader. Mudde and Kaltwasser point out that not all populist leaders are charismatic. And sometimes, it is precisely this lack of charisma which facilitates the process of identification. But Mudde and Kaltwasser do not possess any sophisticated psychological concepts to explain such processes of identification, any more than do Wodak or Moffitt.

In the last two chapters of their short study, the authors turn to debates about populism and democracy, and to the causes of and possible responses to populism. In contrast to Jan-Werner Müller, they do believe that populism can enhance democracy under certain circumstances. Displaying once again their analytical acumen, the authors distinguish between four different types of regimes-full authoritarianism, competitive authoritarianism, electoral democracy and liberal democracyand demonstrate how populism is more likely to benefit democracy under repressive conditions than in a fully open society. They also identify the many ways in which populism can strengthen anti-liberal-democratic tendencies. One problem, however, with this typology is that it posits liberal democracy as the most perfect form of government possible. With this approach, it is difficult, if not impossible, to understand why powerful anti-democratic populist forces develop within liberal democracies. This approach may reflect the limits of political science itself, as a discipline, to provide a comprehensive explanation of right-wing populism, and the need for a more interdisciplinary approach, such as that pioneered by Frankfurt School Critical Theorists in the 1930s and 1940s. ${ }^{3}$ On this same note, Mudde and Kaltwasser begin the sixth and final chapter with the rather surprising statement that, despite the recent explosion of research and writing on populism, "surprisingly few established theories about the success (and failure) of populist forces exist" (Mudde \& Kaltwasser, 2017, p. 97). Like Wodak, they do not seem to believe that there is any single explanation for populism, or even for its global resurgence in the past few decades. They provide a laundry list of conditions, whose existence facilitates populism, such as a perception of threat or crisis, economic downturn, systematic corruption, a weak state unable to collect taxes or redistribute wealth, and an increasingly diversified and competitive media market that focuses more on the sensational issues favored by populists. One of the other causes they mention, namely, the "neo-liberalization of social democracy", that is, the tendency of Socialists and Social Democrats on the Continent, Labor in Britain, and the Democratic Party in the U.S. to embrace neo-liberal economic policies and thereby to abandon any principled opposition to the root cause of growing inequality and insecurity in modern capitalist societies, points to a more comprehensive explanation of the resurgence of populism, but the authors do not develop this idea. The closest they come to a general explanation of the causes of populism is that "many citizens interpret political reality through the lens of populism" (Mudde \& Kaltwasser, 2017 , p. 97), which of course begs the question of why. To come back once more to the Frankfurt School theorists, at least they realized that questions of perception could be linked to socially and historically formed character structures, which were widespread among groups of individuals who shared common experiences. ${ }^{4}$ Such an approach offers the possibility of studying and explaining the reasons why specific forms of perception, and beyond that, specific emotional dispositions, exist among numerically significant groups. These perceptions and dispositions can provide the cement that holds societies together, or-in the case of populist rebellionsthe destructive energy that can transform or tear them apart. Mudde and Kaltwasser end their study with some sound recommendations on how best to counteract the negative effects of populism, which include adequate prosecution for corruption; a stronger state able to collect taxes and redistribute wealth; political and civic education in liberal-democratic values; support for domestic and international institutions that monitor and protect minority rights; and defense of free media. But they also caution that it is a mistake to overreact to the perceived threat of populism, thereby playing into their selfpresentation as victims of powerful forces and violating oneself the democratic principle of the "freedom of those who think differently".

Jan-Werner Müller's What is Populism? (2016) parts ways from the other books under consideration here primarily in its attempt to define populism as an exclusively negative phenomenon, which always represents a potential threat to democracy. To make this argument Müller must also rely on an atypical concept of democracy, in which liberal safeguards to individual and minority rights are included in the definition of the term. Whereas Mudde and Kaltwasser distinguish between democracy and liberal democracy, viewing populism as compatible with the first and a potential threat only to the sec-

\footnotetext{
${ }^{3}$ As Adorno put it: "It cannot be disputed that formal democracy, under the present economic system, does not suffice to guarantee permanently, to the bulk of the population, satisfaction of the most elementary wants and needs, whereas at the same time the democratic form of government is presented as if...it were as close to an ideal society as it could be. The resentment caused by this contradiction is turned by those who fail to recognize its economic roots against the form of democracy itself. Because it does not fulfill what it promises, they regard it as a 'swindle' and are ready to exchange it for a system which sacrifices all claims to human dignity and justice, but of which they expect vaguely some kind of guarantee of their lives by better planning and organization" (Adorno, Frenkel-Brunswick, Levinson, \& Sanford, 1950, p. 678).

${ }^{4}$ See, for example (Horkheimer, 1995a). Erich Fromm's very substantial introductory essay to the Institute's Studies on Authority and Family (Fromm, 1936) also provides an excellent and still relevant model for a sophisticated understanding of the social psychological mechanisms at work in right-wing populist movements. Unfortunately, this important essay has never been translated into English. For a brilliant socio-historical analysis of populist movements in early modern Europe, see also (Horkheimer, 1995b). Horkheimer and Fromm's writings in the 1930s laid the theoretical groundwork for the Institute's path-breaking empirical studies of right-wing populism and authoritarianism in the 1940s and 1950s.
} 
ond, Müller denies the claims of populists in powersuch as Viktor Orban, Hugo Chavez, or Recep Tayyip Erdoğan - to be truly democratic. Müller introduces a new term, "defective democracies", to refer to these regimes, whose success in winning elections is, according to him, not enough to earn them democratic legitimacy. Müller also parts ways from most other commentatorssuch as Moffitt, who argues that populism is successful only in the opposition and tends to collapse if it gains power-in his much greater attention to what populists do when they are in power. Also in contrast to many other scholars of populism, Müller emphasizes the similarities between fascist and populist ideology. Regarding these last two points of divergence, Müller's analysis of populism is informed in illuminating ways by his impressive earlier research on Carl Schmitt, the history of political ideas in twentieth-century Europe, and his more recent work on the Orban regime in Hungary. For example, Müller convincingly demonstrates that contemporary right-wing populists operate with a monolithic and imaginary concept of "the people", which echoes both Schmitt's definition of the political in terms of a binary "friend-enemy" opposition and the National Socialists' appeal to a mythical Volksgemeinschaft. Contemporary populists' appeals to such imagined communities allow them to claim that they represent the "real" people and to exclude those defined as outsiders. For Müller, the "logic" of populism always rests on the self-righteous assumption by populist leaders and followers that "we are the $100 \%$ ". In most cases, however, it is-according to him - the populist leader who speaks in the name of the people. One additional consequence of Müller's thoroughly critical approach to populism is that progressive populism becomes a contradictio in adjecto; for example, he argues that the People Party in the U.S. in the 1890s was social democratic, not populist, and he says basically the same thing about Bernie Sanders. No doubt, Mudde and Kaltwasser's approach, which makes room for progressive, bottom-up forms of populism, is more supple here. But Müller's approach has the advantage of capturing one decisive aspect of right-wing populism that many commentators have overlooked, namely, its tendency to depoliticize its followers and to reduce democracy to a spectacle, in which passive citizens do nothing more than watch or listen to their leaders. Populism can be as much about demobilizing, as mobilizing "the masses", as Schmitt and the Nazis also knew. For populists, popular sovereignty is more acclamatory than participatory. This also helps explain why populism often appeals to people who hate politics.

There is much to recommend in Müller's study, particularly in regard to his trenchant and sobering analysis of populism in power. But I would like briefly to discuss two weaknesses I see in his approach, which he shares with Mudde and Kaltwasser. The first is his positing of liberal democracy as the unquestionable telos of modern politics. Here, Müller goes even further than Mudde and Kaltwasser by uttering some cautious words of praise for
Francis Fukuyama's "end of history" argument, that is, "that there were no more rivals to liberal democracy at the level of ideas" (Müller, 2016, p. 5). As he sees it, the main danger to liberal democracy comes not from rival ideologies, but from within democracy itself, in the form of populism. Although Müller does recognize throughout his study the link between increasing inequality and the resurgence of populism-he goes so far to say that the U.S. "requires deep structural reform in this respect" (Müller, 2016, p. 93)-the question is whether or not he possesses the conceptual tools to grasp the reasons why liberal democracy has come increasingly under threat, from within, during the past few decades. Here, an everrenewed emphasis on the virtues of liberal democracy itself does not get us very far. Adorno's famous statement in 1959 that the survival of authoritarian tendencies within democracy is more menacing than groups openly opposed to democracy, is still relevant-despite the different social and historical context in which we are living today (Adorno, 1998, p. 90). Müller is too quick to caricature and dismiss social-psychological explanations of populism, such as Adorno and his colleagues' analyses of the authoritarian personality. As is the case with the other books considered here, Müller accepts that the psychological mechanism of identification is decisive in the dynamic interaction of the populist leader and his or her supporters. What does liberal democratic political theory have to tell us about this mechanism? Not much, I claim. Furthermore, here also like Mudde and Kaltwasser, Müller does not pay enough attention to the fundamental differences and incompatibility between democratic socialist and Marxist theory, on the one hand, and populism, on the other. While it would take us too far afield to discuss this complex point in any detail here, the case of Ernesto Laclau is very instructive in this regard. In his brilliant early work, Laclau sought to develop a synthesis of critical Marxist theory and populism. But as his work developed, and Laclau's defense of populism as the "ontological" foundation of politics, went hand in hand with a rejection of Marxist and socialist theory, insofar as they insisted that politics must always be theorized within a larger social and historical context. This insistence upon the primacy of the "social", and the compatibility of socialism and populism was precisely what the later Laclau rejected. Not surprisingly, Müller is himself explicitly critical of Laclau, yet he-like Mudde and Kaltwasser-approach populism as a fundamentally political phenomenon, and make little effort to systematically explore the socio-historical and social psychological factors that have determined its success. To his credit, Müller emphasizes that not all criticisms of liberalism are populist. Presumably he is leaving the door open here for a critical Marxist critique of the ways in which social domination reproduces itself within liberal democracy-a critique which is not populist, but democratic socialist. But one will not find such a critique in Müller's own work. Insofar as many people on the left-including Laclau and those influenced by him-have been drawn to populism, 
the development of such a critique remains an important task.

Of all the books under consideration here, John Judis's The Populist Explosion: How the Great Recession Transformed American and European Politics (2016), contributes most to the development of such a critique. Although somewhat misleading, insofar as Judis's discussion of populism extends back historically far beyond the Great Recession of 2008, the title of his book highlights one of its main strengths, namely, an approach to the recent resurgence of populism that is more historical and historically specific than any of the other books under consideration here. Although Judis draws upon political theory-most notably, Ernesto Laclau's emphasis on the fundamentally antagonistic nature of populist politics - to flesh out some of his arguments, at the center of his analysis are deeper socio-economic tendencies and ideologies that have accompanied and reinforced them. He focuses, in particular, on the transition in Europe and the U.S. in 1980s and 1990s from industrial societies governed by more or less Keynesian policies, to post-industrial societies in which neo-liberal ideas and policies had become hegemonic, even among the mainstream leftist parties. Judis views the resurgence of populism in the past few decades primarily as an expression of discontent with neo-liberal policies. So, during periods when neo-liberalism seemed to function well, such as the late 1990s, populism lost support. At other times-most notably in the wake of the 2008 crisisleft and right-wing populist movements exploded in Europe and the U.S. Judis argues compellingly that populist movements "often function as warning signs of a political crisis" and that they arise "only under very special circumstances" (p. 16), which explains why-as most of the other authors also noted-populism was so weak in Europe and the U.S. during the prosperous postwar decades. The populist movements and parties that did exist in Europe during this time-such as the Poujadistes in France-were libertarian, anti-tax parties supported by the petty bourgeoisie. Judis shows interestingly how many European right-wing populist partiessuch as the National Front in France, which had its roots in Poujadisme-followed a trajectory from libertarianism to economic nationalism and pro-welfare state position. With the numbers of immigrants and refugees rising steadily, especially in Northern Europe, right-wing populist parties insisted that the benefits of welfare state policies accrue solely to the "real" people, namely, those within the imagined ethno-nationalist community. Judis also demonstrates a more general tendency in the shifting composition of supporters of European right-wing populist parties, with the petty bourgeois being increasingly outnumbered by workers, and especially workers in regions hit hardest by neo-liberal economic reforms of the 1980s and 1990s. Even relative latecomers to the European right-wing populist scene, such as UKIP in Britain, offer a clear example of this larger pattern outlined by Judis. He argues that UKIP's electoral breakthrough in the
2014 EU election, in which it came in first with $27.5 \%$ of the vote, was predicated upon Nigel Farage's abandonment of the party's commitment to laissez-faire economics, which increased support from workers, especially older, white male workers in former industrial areas. He identifies similar tendencies in other right-wing populist parties in Northern Europe. He argues, for example, that Marine Le Pen-whose home district is a former mining region in Northern France-is more of an economic nationalist than her father and that her economic policies are more important to the current success of the National Front than anti-immigration.

Equally impressive and persuasive is Judis' discussion of the role of the "neo-liberalization of social democracy" in the rise of right-wing populism in Europe and the U.S. Although, as he points out, both center-left and centerright mainstream parties embraced the neo-liberal policies that became hegemonic in the 1980s and 1990s, such a shift had different implications for the left. Everyone is familiar with Bill Clinton and Tony Blair, as the paradigmatic cases of such a shift, but Judis also shows how Continental Social Democracy and Socialism participated in the same dynamic from the early 1980s to the present. From Francois Mitterrand's major concessions to neo-liberalism in the early 1980s, to Gerhard Schroeder's defense of the so-called Hartz laws in 2003, which made it easier to fire workers, to the Spanish and Greek socialist parties' more recent embrace of EUmandated austerity policies, Judis demonstrates a consistent and recurring pattern of the neo-liberalization of Social Democratic parties across Western and Southern Europe. This pattern was reinforced by the EU, which "wittingly or not...institutionalized the rule of neo-liberalism" (Judis, 2016, p. 105) and thereby exerted heavy pressure on Social Democratic and Socialist parties to toe the line. Implied, but never explicitly stated in Judis' argument, is the rather obvious point that if traditional leftist parties, with deep roots in the European universalist traditions of emancipation going back to the French Revolution and socialist movements of the nineteenth-century, fail to articulate a robust critique of neo-liberal global capitalism, then the door is thrown wide open to right-wing populist parties, who are more than willing to criticize neoliberal globalization from a particularist-that is, ethnonationalist and xenophobic-point of view. Thus, if one takes Judis' arguments seriously-as one should-much of the responsibility for the rise of right-wing populism in Europe and the U.S. must be placed squarely at the feet of the Democratic, Labor, Social Democratic and Socialist parties that have failed in this regard. As Judis also points out, such a dynamic also explains the seemingly "surprising" success of left-wing populist movements in the U.S and Europe since 2008-such as Syriza in Greece (before it accepted austerity policies), Podemos in Spain, and Bernie Sanders in the U.S. - which have articulated robust critiques of neo-liberal capitalism and the massive inequality it has created. The election of Donald Trump, who ran his campaign on economic populism 
and promised to transform the Republican Party into a "workers' party", is also much less surprising if one is willing-unlike Hillary Clinton and the Democratic Party leadership-to accept the obvious fact that the Great Recession thoroughly discredited neo-liberal policies. As Judis points out, the success of both Trump and Sanders "showed how much the Great Recession had radicalized significant parts of the electorate...the contrast couldn't have been sharper with Clinton's campaign that lacked any visionary component" (Judis, 2016, pp. 83-84, 86).

Judis concludes his study by arguing-correctlythat we should not simply dismiss right-wing populists as misguided, because they are addressing genuine problems. The problem, however, is to understand why the manner in which they address these genuine problems is indeed misguided, and why such a misguided approach has become so appealing. I have suggested here that contemporary approaches to the study of populism that rely predominantly on discourse analysis, new media, or even political theory are not adequate to the task. Preferable, in my view, would be a return to the sophisticated, interdisciplinary approach to the study of populism that was pioneered by the Frankfurt School Critical Theorists in the 1930s and 1940s, in which a non-dogmatic Marxist critique of capitalism, psychoanalytically based social psychology and empirical social research were combined to grasp the powerful right-wing populist tendencies that emerged in the twentieth century. To be sure, their ideas would need to be updated to reflect contemporary social conditions, and should also draw upon theoretical insights gained by other more recent approaches. But, with the partial exception of John Judis, contemporary studies of populism seem better at describing than actually explaining the ominous resurgence of right-wing populism in Europe and the U.S. in recent times.

\section{Acknowledgments}

The author would like to thank Samir Gandesha, Claudia Leeb and the anonymous reviewers for helpful feedback on earlier drafts of this review article.

\section{Conflict of Interests}

The author declares no conflict of interests.

\section{References}

Abromeit, J. (2016). Transformations of producerist populism in Western Europe. In J. Abromeit, B. M. Chesterton, G. Marotta, \& Y. Norman (Eds.), Transformations of populism in Europe and the Americas: History and recent tendencies (pp. 231-264). London and New York, NY: Bloomsbury.
Abromeit, J., Chesterton, B. M., Marotta, G., \& Norman, Y. (Eds.). (2016). Transformations of populism in Europe and the Americas: History and recent tendencies. London and New York, NY: Bloomsbury.

Adorno, T. (1998). The meaning of working through the past. (H. W. Pickford, Trans.). In T. Adorno (Ed.), Critical models: Interventions and catchwords (pp. 89-104). New York, NY: Columbia University Press.

Adorno, T., Frenkel-Brunswick, E., Levinson, D. J., \& Sanford, R. N. (1950). The authoritarian personality. New York, NY: Harper \& Brothers.

Finchelstein, F. (2017). From fascism to populism in history. Berkeley and Los Angeles, CA: University of California Press.

Fromm, E. (1936). Sozialpsychologischer Teil [Socialpsychological section]. In M. Horkheimer (Ed.), Studien über Autorität und Familie [Studies on authority and family] (pp. 77-135). Paris: Felix Alcan.

Gellner, E., \& Ionescu, G. (Eds.). (1969). Populism: Its meaning and national characteristics. London: Weidenfeld \& Nicholsen.

Horkheimer, M. (1995a). History and psychology (J. Torpey, Trans.). In M. Horkheimer (Ed.), Between philosophy and social science: Selected early writings (pp. 111-128). Cambridge, MA: MIT Press.

Horkheimer, M. (1995b). Egoism and freedom movements: On the anthropology of the bourgeois era (G. F. Hunter, Trans.) In M. Horkheimer (Ed.), Between philosophy and social science: Selected early writings (pp. 49-110). Cambridge, MA: MIT Press.

Judis, J. B. (2016). The populist explosion: How the great recession transformed American and European Politics. New York, NY: Columbia Global Reports.

Leeb, C. (in press). A festival for frustrated egos: The rise of trump from an early Frankfurt School Critical theory perspective. In A. Jaramillo \& M. Sable (Eds.), Trump and political philosophy. London: Palgrave Macmillan.

Moffitt, B. (2016). The global rise of populism: Performance, political style and representation. Stanford, CA: Stanford University Press.

Mudde, C., \& Kaltwasser, C. R. (Eds.). (2012). Populism in Europe and the Americas: Threat or corrective for democracy? Cambridge and New York, NY: Cambridge University Press.

Mudde, C., \& Kaltwasser, C. R. (2017). Populism: A very short introduction. New York, NY: Oxford University Press.

Müller, J. (2016). What is populism? Philadelphia, PA: University of Pennsylvania Press.

Wodak, R. (2016). The politics of fear: What right-wing populist discourses mean. Los Angeles, CA, London, New Delhi, Singapore and Washington, DC: Sage. 


\section{About the Author}

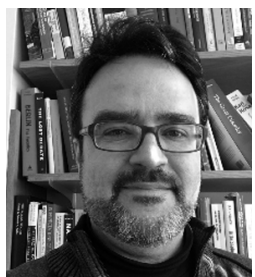

John Abromeit is an Associate Professor of History at SUNY, Buffalo State. He is the author of Max Horkheimer and the Foundations of the Frankfurt School (Cambridge University Press, 2011) and the lead editor of Transformations of Populism in Europe and the Americas: History and Recent Tendencies (Bloomsbury, 2016) His scholarly writings have appeared in Constellations; Theory, Culture and Society; Radical Philosophy; The German Quarterly; The American Historical Review; The Journal of Modern History; and Critical Historical Studies. 